JURNAL RISET MAHASISWA AKUNTANSI

http://ejournal.unikama.ac.id/index.php/jrma

JRMA, Volume 7, No 1 April 2019

\title{
NILAI TUKAR RUPIAH, INFLASI, SUKU BUNGA DAN CURRENT RATIO (CR) TERHADAP RETURN SAHAM
}

\author{
Dewi Siti Rukmana \\ Email: rukmanadewisiti12@gmail.com \\ Alfinur \\ Supami Wahyu Setiyowati \\ (Program Studi Akuntansi, Fakultas Ekonomika dan Bisnis, Universitas Kanjuruhan Malang)
}

\begin{abstract}
ABSTRAK
Penelitian ini bertujuan untuk mengetahui secara empiris pengaruh nilai tukar rupiah, inflasi, suku bunga, dan Current Ratio (CR) perusahaan real estate and property terhadap return saham perusahaan real estate and property yang terdaftar di Bursa Efek Indonesia (BEI) pada tahun 2015-2017. Penelitian ini menggunakan variabel independen Nilai tukar rupiah, inflasi, suku bunga, dan current ratio, sedang variabel dependennya adalah Return saham. Populasi sebanyak 44 perusahaan Real Estate and Property yang go public dan sampel yang digunakan sebanyak 33 perusahaan dengan menggunakkan metode penelitian explanatory research. Hasil penelitian ini menunjukkan bahwa nilai tukar rupiah, inflasi, suku bungat, current ratio (CR) secara simultan berpengaruh terhadap return saham, secara parsial nilai tukar rupiah dan inflasi berpengaruh negatif terhadap return saham, sedangkan suku bunga dan current ratio (CR) berpengaruh positif terhadap return saham. Sebaiknya manajemen perusahaan meningkatkan kinerja keuangan, terutama terhadap efisiensi operasional usaha dan kemampuan laba, agar investor semakin percaya terhadap kinerja keuangan perusahaan.
\end{abstract}

Kata kunci: Return Saham, Inflasi, Suku Bunga, Rasio Lancar (CR) dan Nilai Tukar Rupiah

\begin{abstract}
This study aims to determine empirically the influence of the exchange rate of the rupiah, inflation, interest rates, and Current Ratio (CR) of real estate and property companies to the stock returns of real estate and property companies listed on the Indonesia Stock Exchange (IDX) in 2015-2017 This study uses the independent variable Rupiah exchange rate, inflation, interest rates, and current ratio, while the dependent variable is Stock Return. The population of 44 Real Estate and Property companies that went public and the sample used were 33 companies using explanatory research methods research. The results of this study indicate that the rupiah exchange rate, inflation, interest rates, current ratio (CR) simultaneously affect stock returns, partially the rupiah exchange rate and inflation negatively affect stock returns, while interest rates and current ratios (CR) have a positive effect on stock returns. The company management should improve financial performance, especially on business operational efficiency and profitability, so that investors can trust the company's financial performance.
\end{abstract}

Keynotes: Stock Returns, Inflation, Interest Rates, Current Ratio (CR) and Rupiah Exchange Rates 


\section{PENDAHULUAN}

Perusahaan dalam meningkatkan labanya dapat menempuh berbagai cara, salah satunya yaitu dengan berinvestasi di pasar modal. Kegiatan investasi merupakan penundaan konsumsi sekarang untuk dimasukkan ke aktiva produktif selama periode waktu tertentu (Hartono, 2014).Return Saham adalah nilai yang diperoleh sebagai hasil dari aktivitas investasi. Return saham diharapkan berupa deviden untuk investasi saham dan pendapatan bunga untuk investasi di surat utang. Return merupakan tujuan utama investor untuk mendapatkan hasil dari investasi yang dilakukan oleh investor ( Jogiyanto, 2010:205).Dengan adanya return saham yang cukup tinggi akan lebih menarik para investor untuk membeli saham tersebut.

Pasar modal memberikan fasilitas untuk mempertemukan antara pihak investor. Disitulah pasar modal memiliki peran penting, dimana pertumbuhan investasi mengalami pergerakan ekonomi secara circle, mulai dari sektor keuangan sampai dengan banyaknya investor yang telah menanamkan modalnya dalam bentuk saham di industri Real estate and Property. Perkembangan sektor real estate and property yang semakin pesat diikuti dengan semakin tingginya permintaan akan kebutuhan papan atau tempat tingginya permintaan akan kebutuhan papan atau tempat tinggal, sehingga emiten-emiten sektor property membutuhkan dana dari sumber eksternal.

Penelitian tentang pengaruh nilai tukar rupiah terhadap return saham telah dilakukan Saputra dan Dharmadiaksa (2016) dan Feoriko (2013 menunjukkan bahwa nilai turak rupiah per dollar AS berbengaruh negative terhadap return. Penelitian Oktiar (2014) dan martin at al (2015) menunjukkan hasil bahwa inflasi berpengaruh negatif signifikan terhadap return saham. Hasil penelitian Habib Azwa (2016) menujukkan bahwa Current Ratio (CR) berpengaruh positif dan signifikan terhadap return saham.

Tujuan penelitian ini adalah menguji pengaruh nilai tukar rupiah, inflasi, suku bunga, dan Current Ratio (CR) perusahaan real estate and property terhadap return saham perusahaan real estate and property yang terdaftar di Bursa Efek Indonesia (BEI) pada tahun 2015-2017.

\section{TINJAUAN PUSTAKA DAN PERUMUSAN HIPOTESIS Return Saham}

Return saham adalah nilai yang diperoleh sebagai hasil dari aktivitas investasi. Retunn yang diharapkan berupa deviden untuk investasi saham dan pendapatan bunga untuk investasi di surat utang. Return merupakan tujuan utama investor untuk mendapatkan hasil dari investasi yang dilakukan oleh investor (jogiyanto, 2015:205). Dengan adanya return saham yang cukup tinggi akan lebih menarik para investor untuk membeli saham tersebut.

Return dari suatu investasi tergantung dari instrumen investasi yang dibelinya. Misalnya ivestasi dalam saham, saham tidak menjanjikan suatu return yang pasti bagi para pemodal, namun beberapa komponen return pada saham yang memungkinkan pemodal meraih keuntungan adalah dividen, saham bonus, dan capital gain. Faktor yang mempengaruhi Return suatu investasi meliputi faktor internal dan faktor eksternal perusahaan. Faktor internal perusahaan meliputi kualitas dan reputasi manajemen, struktur hutang, tingkat laba yang dicapai, dan lain-lain. Sedangkan faktor eksternal meliputi pengaruh kebijakan moneter dan fiskal, perkembangan sektor industri, faktor ekonomi, dan sebagainya. return/tingkat pengembalian dari suatu investasi dibedakan menjadi dua yaitu return yang telah terjadi (realized return) berdasarkan data historis. Return yang diharapkan oleh para investor akan diperoleh dimasa yang akan datang (expeted return).

\section{Teori Return Saham}


a) Capital Asset Pricing Model (CAPM) dan Arbitrage Pricing Theory (APT)

Return saham merupakan salah satu faktor yang memotivasi investor untuk berinvestasi dan juga merupakan imbalan atas keberanian investor menanggung risiko atas investasi yang dilakukannya. Pembahasan tentang tingkat sebuah keuntungan sekuritas dapat dikelompokan dalam dua teori yaitu Capital Asset Pricing Model (CAPM) dan Arbitrage Pricing Theory (APT) (Suad Husnan, 2005).

Capital Asset Pricing Model (CAPM) gambaran tentang hubungan tingkat return dan risiko secara sederhana dan hanya menggunakan satu variabel (variabel beta) untuk menggambarkan risiko. Sedangkan Arbitrage Pricing Theory (APT) menggunakan berbagai variabel pengukur risiko untuk melihat hubungan return dan risiko atau dengan kata lain APT tidak menjelaskan faktor-faktor apa yang mempengaruhi pricing (Tandelilin, 2001).

b) Agency Theory

Teori agensi merupakan kontrak diantara manajemen selaku agent dan juga pemegang saham selaku principal Agent diberikan kepercayaan dan wewenang dalam mengeloa kekayaan yang dimiliki oleh principal selain itu agent juga dipercaya dalam hal pengambilan keputusan sesuai dengan kepentingan principal. Agent selaku manajer dalam perusahaan dalam hal memiliki informasi, lebih baik dibandingkan para pemegang saham tentang kondisi dari perusahaan.

c) Signal Theory

Isyarat atau signal adalah suatu tindakan yang diambil manajemen perusahaan untuk memberi petunjuk bagi investor tentang bagaimana manajemen memandang prospek perusahaan, perusahaan dengan prospek yang menguntungkan akan mencoba menghindari penjualan saham dan mengusahakan setiap modal baru yang diperlukan dengan cara-cara lain, termasuk penggunaan hutang yang melebihi target struktur modal yang normal (Brigham dan Houston, 2014).

\section{Nilai Tukar Rupiah}

Nilai tukar mata uang atau yang sering disebut dengan kurs adalah harga satu mata uang asing dalam mata uang domestik atau dapat juga dikatakan harga mata uang domestik terhadap mata uang asing (Firdaus dan Ariyanti, 2011:131).Nilai dari suatu mata uang negara mencerminkan tingkat perekonomian negara itu sendiri. Tinggi rendahnya nilai tukar mata uang suatu negara dapat diketahui dengan cara membandingkannya dengan nilai tukar mata uang negara lain yang sudah ditetapkan oleh Negara. Banyak hal yang dapat mempengaruhi perubahan krus mata uang suatu Negara dengan Negara lain yang langsung maupun tidak langsung dapat. Dengan adanya nilai tukar mata uang juga akan berpengaruh terhadap ekonomi masyarakat negara itu sendiri.

\section{Inflasi}

Inflasi diartikan sebagai meningkatnya harga secara umum dan terus menerus.Menurut Badan Pusat Statistik (2014) Inflasi adalah "kenaikan harga barang dan jasa secara umum dimana barang dan jasa tersebut merupakan kebutuhan pokok persyaratan atau turunya daya jual mata uang suatu negara."Inflasi adalah kecenderungan dari harga-harga yang meningkat secara umum dan terusmenerus bergerak secara signifikan. Kenaikan harga dari satu atau dua barang saja tidak disebut inflasi, kecuali bila kenaikan itu meluas kepadda sebagaian besar dari harga barang-barang lain. Menurut Sadono Sukirno (2007), kenaikan harga-harga umum atau inflasi (P) disebabkan oleh tiga faktor yaitu jumlah uang beredar $(\mathrm{M})$, kecepatan peredaran uang $(\mathrm{V})$, dan jumlah barang yang diperdagangkan $(\mathrm{T})$.

\section{Suku Bunga}

Suku bunga adalah presentase dari pokok utang yang dibayarkan sebagai imbalan jasa (bunga) dalam suatu periode tertentu.Menurut dunia perbankan merupakan harga yang harus dikeluarkan 
bank kepada nasabah yang menyimpan dananya di bank. Disisi lain, dapat dikatakan pula sebagai harga yang hasur dibayarkan nasabah kepada bank atas dana yang telah dipinjamkan bank. Menurut Mankiw (2003: 86), tingkat suku bunga adalah harga yang menghubungkan masa kini dengan masa depan.Suku bunga merupakan satu variable dalam perekonimian yang senantiasa diamati secara cermat karena dampaknya yang luas.Bunga mempengaruhi secara langsung kehidupan masyarakat pada keseharian dan mempunyai dampak penting terhadap kesehatan perekonomian Negara itu sendiri mulai dari segi konsumsi, kredi, obligasi, serta tabungan.

\section{Current Ratio (CR)}

Current Ratio (CR) adalah rasio untuk mengukur kemampuan perusahaan dalam membayar kewajiban/hutang jangka pendek yang segera jatuh tempo pada saat ditagih secara keseluruhan.Apabila rasio lancar rendah, maka dapat dikatakan bahwa perusahaan kurang modal untuk membayar utang.Namun apabila hasil pengukuran rasio tinggi, belum tentu kondisi perusahaan sedang dalam keadaan baik-baik saja.Hal ini dapat terjadi karena kas tidak digunakan dengan baik.Rasio yang rendah menunjukkan rasio likuiditas yang tinggi, sedangkan rasio lancar yang tinggi menunjukkan adanya kelebihan aktiva lancar, yang akan mempunyai pengaruh yang tidak baik terhadap profitabilitas perusahaan. Aktiva lancar secara umum menghasilkan return saham yang lebih rendah dibandingkan dengan aktiva tetep (Mamduh, 2016:75).

\section{Real Estate And Property}

Real estate adalah sebagai kawasan tanah beserta bangunan diatasnya termasuk dengan properti hak milik bangunan yang ada, bersama sumberdaya alamnya seperti tanaman, air, mineral, dan benda lainnya yang ada di alam yang tidak bergerak sekalipun yang sering disebut kawasan indah dan elit.Perusahaan real estate dan property pada umumnya merupakan dua hal yang berbeda. Real estate merupakan tanah dan semua yang berada di atasnya termasuk bangunan-bangunan, seperti gedung, pembangunan jalan, tanah terbuka, dan segala bentuk pengembangan lainnya yang melekat secara permanen. Menurut peraturan perundang-undangan di Indonesia, pengertian mengenai industri real estate tercantum dalam PDMN No.5 Tahun 1974 yang mengatur tentang industri real estate. Dalam peraturan ini pengertian industri real estate merupakan perusahaan properti yang bergerak pada bidang penyediaan, pengadaan, serta pematangan tanah bagi keperluan usaha-usaha industri, termasuk industri pariwisata. Sedangkan definisi property menurut SK Menteri Perumahan Rakyat no.05/KPTS/BKP4N/1995, Ps 1.a:4 property adalah tanah hak dan atau bangunan permanen yang menjadi objek pemilik dan pembangunan. Dalam hal ini property adalah industri real estate ditambah dengan hukum-hukum seperti sewa dan kepemilikan.

\section{Hipotesis}

Berdasarkan kajian teori dan kerangka pemikiran yang telah dijabarkan maka dapat dirumuskan hipotesis sebagai berikut:

Ha.1 : Nilai tukar rupiah, inflasi, suku bunga, dan Current Ratio (CR) berpengaruh secara simultan terhadap Return Saham

Ha. 2 : Nilai tukar rupiah mempunyai pengaruh terhadap return saham.

Ha. 3 : Inflasi berpengaruh terhadap return saham

Ha. 4 : Suku bunga berpegaruh terhadap return saham

Ha. 5 : Current Ratio (CR) berpegaruh terhadap return saham 


\section{METODE PENELITIAN}

Objek penelitian yang digunakan sebagai batasan dalam penelitian ini yaitu perusahaan real estate and property yang terdaftar di Bursa Efek Indonesia (BEI) tahun 2015-2017. Adapun variabelvariabel yang menjadi fokus utama dalam penelitian ini yaitu Nilai Tukar Rupiah, Inflasi, Suku Bunga, Current Ratio (CR), dan Return saham.

Populasi dalam penelitian ini adalah 44 perusahaan Real estate and Property yang terdaftar di BEI.Berdasarkan kriteria tersebut yang menjadi sampel dalam penelitian ini adalah 33 perusahaan yang terdaftar di Bursa Efek Indonesia yang digunakan sebagai sampel. Penelitian ini menggunakan jenis data kuantitatif yaitu jenis data yang berbentuk angka, dapat diamati secara fisik, dicatat, diklasifikasikan dan diolah berdasarkan waktu dan tempat sesuai dengan peristiwa (Ghozali, 2006).

\section{HASIL PENELITIAN DAN PEMBAHASAN}

Berdasarkan Tabel 4.10 model persamaan regresi sebagai berikut:

$Y=\beta+\beta 1 X 1+\beta 2 X 2+\beta 3 X 3+\beta 4 X 4$

$Y=1,643-0,199$ NilaiTukar -0,103 Inflasi 0 ,103 Suku Bunga $+0,21$ CR

Berdasarkan persamaan diatas dapat dijelaskan sebagai berikut:

Koefisien regresi variabel ukuran perusahaan bertanda negatif -0,199. Hal ini menunjukkan bahwa variabel nilai tukar rupiah berhubungan negatif terhadap return saham pada perusahaan Real Estate and Property yang terdaftar di Bursa Efek Indonesia periode 2015-2017.

Koefisien regresi variabel Inflasi adalah -0,103. Hal ini menunjukkan bahwa variabel inflasi berhubungan negatif terhadap return saham pada perusahaan Real Estate and Property yang terdaftar di Bursa Efek Indonesia periode 2015-2017.

Koefisien regresi variabel suku bunga bertanda positif 0,103. Hal ini menunjukkan bahwa variabel suku bunga berhubungan positif terhadap return saham pada perusahaan Real Estate and Property yang terdaftar di Bursa Efek Indonesia periode 2015-2017.

Koefisien regresi variabel current ratio (CR) bertanda positif 0,21 . Hal ini menunjukkan bahwa variabel rupiah current ratio (CR) berhubungan positif terhadap return saham pada perusahaan Real Estate and Property yang terdaftar di Bursa Efek Indonesia periode 2015-2017.

Hasil uji hipotesis

H1 : Nilai tukar rupiah, Inflasi, Suku Bunga dan Current Ratio (CR) Terhadap Return Saham.

Hasil uji simultan yang menunjukkan nilai signifikansi sebesar 0,000 lebih kecil dari 5\% atau 0,05. Nilai tersebut menunjukkan bahwa variabel independen yaitu X1, X2, X3, X4 secara simultan berpengaruh terhadap variabel dependen $Y$. Hal ini menunjukkan bahwa secara simultan variabel independen berpengaruh positif signifikan terhadap variabel dependen, sehingga hipotesis pertama diterima.

H2 : Nilai Tukar Rupiah terhadap Return Saham.

Variabel nilai tukar rupiah memiliki nilai koefisien regresi sebesar -0,199 yang menunjukkan terdapat pengaruh negatif nilai tukar rupiah terhadap return saham. Hasil uji $t$ variabel nilai tukar rupiah sebesar -0,199 dengan nilai signifikansi sebesar 0.096 lebih besar dari alpa 0,05. Uji t memiliki hubungan yang negatif terhadap return saham. Hal ini menunjukkan bahwa secara parsial nilai tukar rupiah berpengaruh negatif tetapi tidak signifikan terhadap return saham, sehingga hipotesis kedua ditolak.

H3 : Inflasi berpengaru terhadap Return saham 
Variabel inflasi memiliki nilai koefisien regresi sebesar -0,103 yang menunjukkan terdapat pengaruh negatif inflasi terhadap return saham. Hasil uji t variabel struktur aset menunjukkan nilai 0,103 dan signifikansi sebesar 0.001 lebih kecil dari alpa 5\% atau 0,05. Uji t memiliki hubungan yang positif terhadap return saham. Hal ini menunjukkan bahwa secara parsial inflasi berpengaruh negative dan signifikan terhadap return saham. Dengan demikian, hipotesis ketiga diterima.

H4: Suku bunga memiliki pengaruh terhadap return saham

Variabel pertumbuhan penjualan memiliki nilai koefisien regresi sebesar 0,103 yang menunjukkan terdapat pengaruh positif suku bunga terhadap return saham. Hasil uji t variabel suku bunga menunjukkan nilai 0,103 dan signifikansi sebesar 0,000 lebih kecil dari alpa 5\% atau 0,05. Uji t memiliki hubungan yang positif terhadap return saham. Hal ini menunjukkan bahwa secara parsial suku bunga berpengaruh positif dan signifikan terhadap return saham, sehingga hipotesis keempat ditolak.

H5 : Current Ratio (CR) berpengaruh terhadap return saham

Variabel likuiditas memiliki nilai koefisien regresi sebesar 0,021 yang menunjukkan terdapat pengaruh positif pertumbuhan penjualan terhadap return saham. Hasil uji t variabel Current Ratio (CR) menunjukkan nilai 0,021 dan signifikansi sebesar 0,312 lebih besar dari alpa 5\% atau 0,05. Uji t memiliki hubungan yang positif terhadap return saham. Hal ini menunjukkan bahwa secara parsial Current Ratio (CR) berpengaruh positif tetapi tidak signifikan terhadap return saham. Dengan demikian, hipotesis kelima ditolak.

Pembahasan penagaruh Nilai Tukar Rupiah, Inflasi, Suku Bunga dan Current Rasio terhadap Return Saham, Berdasarkan hasil uji simultan pada penelitian ini menunjukkan bahwah signifikansi F hitung dan signifinkasn yang baik. Yang berarti bahwa model ini dapat digunakan memprediksi pengaruh nilai tukar rupiah, inflasi, suku bunga, dan Current Ratio (CR) terhadap return saham. Hasil analisis ini menunjukkan bahwa melemahnya nilai tukar rupiah atau depresiasi menandakan bahwa faktor fundamental perekonomian Indonesia sedang melemah. Inflasi yang tinggi akan menyebabkan suku bunga menjadi meningkat dan akan mengurangi tingkat investasi. Dalam kondisi ini biasanya pemerintah akan menaikkan suku bunga untuk mengurangi jumlah uang yang beredar di masyarakat. Namun kenaikan bunga tersebut akan menyebabkan investor yang enggan melakukan investasi karena bunga pinjaman yang harus dibayarkan menjadi lebih tinggi.

Hasil penelitian yang memperkuat teori di atas adalah penelitian yang dilakukan oleh Saputra dan Dharmadiaksa (2016) juga menunjukkan hal yang sama, yaitu nilai tukar rupiah per dollar AS berpengaruh negative terhadap return saham. Penelitian yang dilakukan oleh Feoriko (2013) menunjukkan hasil bahwa nilai turak rupiah per dollar AS berbengaruh negative terhadap return saham. Selain itu penelitian yang dilakukan oleh Pujawati, Wiksuana, dan Artini (2015) jiga memperkuat teori di atas dalam penelitiannya memberikan hasil bahwa nilai tukar rupiah per dollar AS berpengaruh negatif terhadap return saham.

Inflasi yang tinggi akan menyebabkan suku bunga yang meningkat dan akan mengurangi tingkat investasi. Dalam kondisi seperti ini inflasi biasanya pemerintah akan menaikkan suku bunga untuk mengurangi jumlah uang yang beredar di masyarakat. Namun kenaikan bunga tersebut akan menyebabkan investor yang enggan melakukan investasi karena bunga pinjaman yang harus dibayarkan menjadi lebih tinggi. Pada kondisi seperti ini investor lebih suka menyimpan dana di bank dan memperoleh pendapatan dari bunga tabungan dan pasar saham menjadi tidak menarik. Kenaikan tingkat bunga akan mengakibatkan harga saham bereaksi secara negative yaitu harga saham menurun dengan demikian return saham akan turun. Sedangkan perubahan sebaliknya ata suku bunga maka akan menaikkan return saham. Jumlah uang yang beredar dengan pertumbuhan 

yang wajar memberikan pengaruh positif terhadap ekonomi dan pasar ekuitas secara jangka pendek.pertumbuhan yang drastis akan memicu inflasi yang tentunya memberikan pengaruh negative terhadap pasar ekuitas (Heru nugroho, 2008).Hasil penelitian yang memperkuat teori diatas adalah penelitian yang dilakukan oleh Oktiar (2014) yang menunjukkan hasil bahwa inflasi berpengaruh negatif signifikan terhadap return saham. Selain itu, penelitian yang dilakukan oleh Martin at al (2015) juga menunjukkan hal yang sama, yaitu inflasi berpengaruh negatif dan signifikan terhadap return saham.

Curretn Ratio (CR) yang rendah akan menyebabkan tingginya penurunan harga pasra dari saham yang bersangkutan. Sebaliknya jika Curretn Ratio (CR) terlalu tinggi juga belum tentu baik, karena pada kondisi tertentu hal tersebut menunjukkan banyak dana perusashaan yang menganggur atau aktivitas sedikir yang akhirnya dapat mengurangi laba perusahaan. Adanya Curretn Ratio (CR) yang tinggi dapat dikarenakan oleh adanya piutang yang tertagih dan persediaan yang belum terjual, yang tentunya tidak dapat digunakan secara cepat untuk membayar hutang.Perusahaan yang memiliki nilai Curretn Ratio (CR) yang besar akan menjadi daya tarik investor dalam membeli saham. Permintaan yang semakin meningkat terhadap saham perusahaan akan menyebabkan harga saham perusahaan menjadi semakin naik. Harga saham yang naik akan menyebabkan return yang diterima oleh investor menjadi semakin besar. Penjelasan tersebut, disimpulkan bahwa Curretn Ratio (CR) berpengaruh positif terhadap Return Saham.

Habib Azwa (2016) melakukan penelitian pada perusahaan Property yang terdaftar di Bursa Efek Indonesia membuktikan bahwa Current Ratio (CR) berpengaruh positif dan signifikan terhadap return saham.emakin tinggi Current Ratio (CR), berarti semakin besar kemampuan perusahaan untuk memenuhi kewajiban jangka pendeknya secara lebih baik, karena perusahaan yang memiliki Current Ratio (CR) yang tinggi cenderung mempunyai aset lancar yang lebih seperti kas, piutang dagang, persediaan, dan aset lancar lainnya yang dapat dicairkan sewaktu-waktu tanpa mengalami penurunan nilai pasarnya.

\section{KESIMPULAN}

Nilai Tukar Rupiah, Inflasi, Suku Bunga dan Current Ratio (CR) secara simultan berpengaruh signifikan terhadap Return Saham pada perusahaan Estate and Property yang terdaftar di BEI periode 2015-2017. Nilai Tukar Rupiah berpengaruh negatif dan tidak signifikan terhadap Return Saham pada perusahaan Real Estate and Property yang terdaftar di BEI periode 2015-2017.Inflasi berpengaruh negatif dan signifikan terhadap Return Saham pada perusahaan Real Estate and Property yang terdaftar di BEI periode 2015-2017,). Suku Bunga berpengaruh positif dan signifikan terhadap Return Saham pada perusahaan Estate and Property yang terdaftar di BEI periode 20152017.Current Ratio (CR)berpengaruh positif dan tidak signifikan terhadap Return Saham pada perusahaan Estate and Property yang terdaftar di BEI periode 2015-2017.

\section{DAFTAR PUSTAKA}

Badan Pusat Statistik (2014)

Brigham, Eugene F. dan Joul F Houston. 2014. Dasar-Dasar Manajemen Keuangan. Jakarta: Salemba Empat.

Faoriko, A. (2013). Pengaruh Inflasi, Suku Bunga, dan Nilai Tukar Rupiah terhadap Return Saham di Bursa Efek Indonesia Ejurnal 6 (4). Universitas Negeri Yogyakarta. 
Firdaus, R. \& Arianti M. (2011). Manajemen Perkreditan Bank Umum: Teori, Masalah, Kebijakan, dan Aplikasi Lengkap dengan Analisis Kredit. Bandung: Alfabeta.

Ghozali, I, 2006, Aplikasi Analisis Multivariate Dengan SPSS, Universitas Diponegoro, Semarang.

2005. Aplikasi Analisis Multivariat Dengan SPPS, Ed. Ketiga, Badan Penerbit Universitas Diponegoro, Semarang.

Habib, A. (2016). Pengaruh Faktor Fundamental dan Risiko Sistematik terhadap Return Saham Perusahaan Sektor Property di Bursa Efek Indonesia. EJurnal 5 (2) Universitas Negeri Yogyakarta.

Hartono, J.. (2014). Teori portofolio dan Analisis Investasi. (Edisi 9). Yogyakarta: BPFE.

Heru Nugroho. 2008. Analisis Pengaruh Inflasi, Suku Bunga, Kurs dan Jumlah Uang Beredar Terhadap Indeks LQ45 (Studi Kasus Pada BEI Periode 2002-2007). EJurnal 4 (2)Semarang: Program Studi Magister Manajemen Program Pascasarjana. Universitas Diponegoro

Husnan, Suad, 1998, Dasar-dasar Teori Portfolio dan Analisis Sekuritas, UPP AMP.YKPN

Jogiyanto. (2009). Teori Portofolio dan Analisis Investasi. Edisi Keenam. Cetakan Pertama. Yogyakarta : PT.BPFE Yogyakarta.

(2015). Teori Portofolio dan Analisis Investasi. Jogjakarta: BPFE.

Mamduh M. Hanafi dan Abdul Halim, Analisis Laporan Keuangan, UPP AMP YKPN, Yogyakarta, 2003.

Mankiw, N. J. (2003). Teori Makro Ekonomi. (Edisi 5). (Terjemahan Imam Nurmawan). Jakarta: Erlangga. (Edisi asli diterbitkan Tahun 1809 oleh South-Western College Publication).

Saputra, I G. A. A. \& Dharmadiaksa, I. B. (2016). Pengaruh Tingkat Suku Bunga, Nilai Tukar Rupiah, Leverage, dan Profitabilitas pada Return Saham. EJurnal Akuntansi Universitas Udayana, 16 (2), 1007-1033.

Sukirno, Sadono.2007.Teori Pengantar Makro Ekonomi. Edisi Ketiga. PT. Raja Grafindo Persada.Jakarta, 2007.hm.230

Sugiyono. 2014. Metode Penelitian Bisnis (Pendekatan Kuantitatif, Kualitatif, dan R\&D). Bandung: Alfabeta

Tandelilin, E. (2001). Analisis Investasi dan Manajemen Portofolio. (Edisi 1). Yogyakarta: BPFE Yogyakarta. 